\title{
Characteristic Analysis and Trial Manufacture of Permanent-Magnetic Type Linear Generator
}

\author{
Kenji Takahara Member (Fukuoka Institute of Technology, takahara@ fit.ac.jp) \\ Shingo OhsakiＭember (Sindengen, s_osaki@shindengen.co.jp) \\ Yuzo Itoh Senior Member (Fukuoka Institute of Technology) \\ Kazuhiro Ohyama Member (Fukuoka Institute of Technology, ohyama@ee.fit.ac.jp) \\ Hideki Kawaguchi Member (Muroran Institute of Technology, kawa@mmm.muroran-it.ac.jp)
}

Keywords: linear generator, vibration, magnetic field analysis, finite element method, detent force

This paper describes design and trial manufacture of the linear generator, which can convert any mechanical vibration of an automobile to electric energy.

A mover, which includes permanent magnets, is linearly driven through a stator, by vibrations. Nd Fe-B magnets in the mover are placed as same magnetic poles face mutually, in order to make the change of magnetic flux in the coils of the stator. The coils are placed in the stator with same intervals of magnets. The coils are wound for the reverse to the next coil and they are connected series all. A magnetic material case covers the stator makes the magnetic flax is extended through the case and decrease canceling the flux in the coils of the stator. Figure 1 shows the fundamental structure of the linear generator.

Numerical simulations calculated distribution of the magnetic field, electromotive force and driven power of the mover by the finite element method, in order to determine the size of the linear power generator. The calculated output voltage is shown in Fig. 2 .

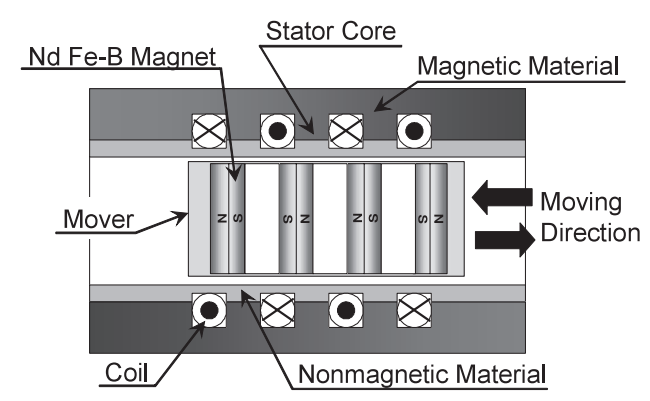

Fig. 1. Fundamental structure of the linear generator

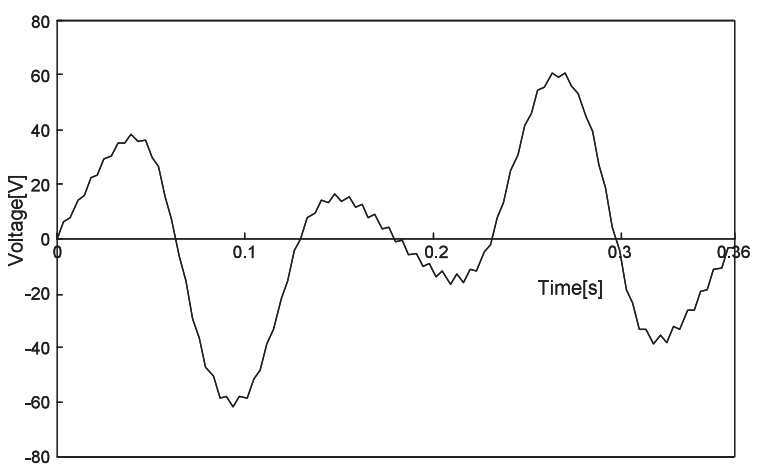

Fig. 2. Calculated output voltage

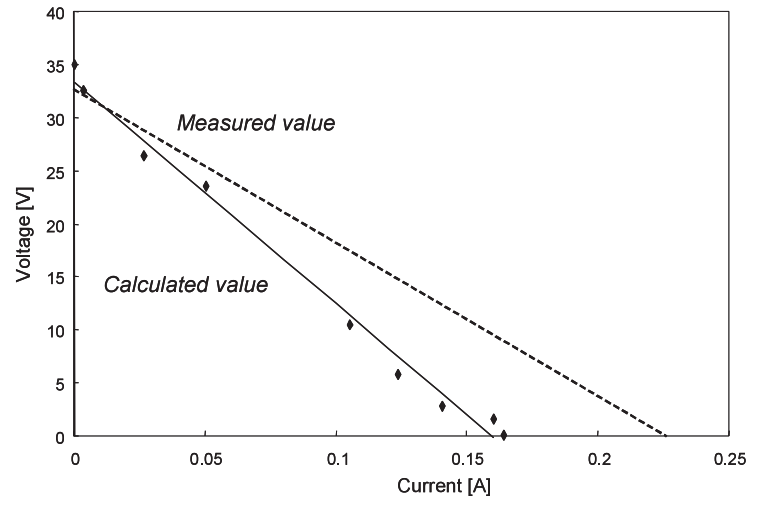

Fig. 3. Current-voltage characteristics

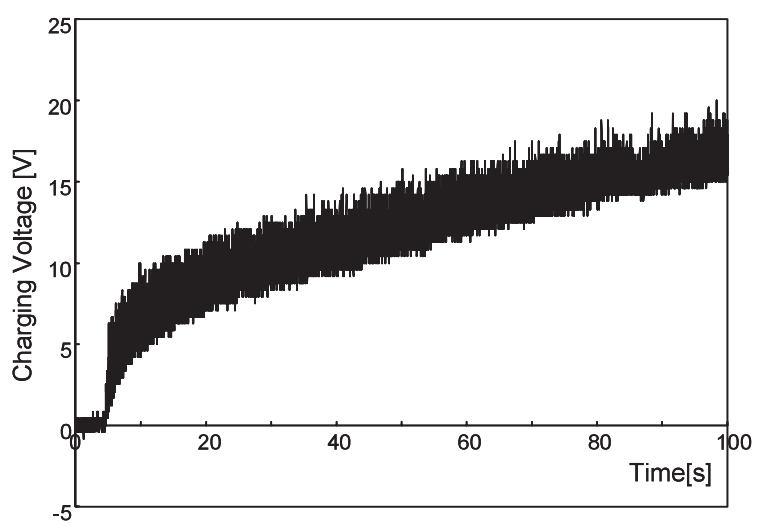

Fig. 4. Charging voltage to condenser

Based on the simulation result, the linear generator was produced experimentally. The current-voltage characteristics of the produced linear power generator are shown in Fig. 3. The calculated values are shown by the same figure for the comparison in broken line. The current-voltage characteristics were measured by the output voltage with full-wave rectification applying to variable resistor. The maximum power of 1.28 [W] was obtained at the optimum load impedance of $200[\Omega]$.

Figure 4 illustrates the change in the charging voltage to the electric double-layer capacitor. It was possible to charge to $12[\mathrm{~V}]$ in about 60 [s], and to charge to $16[\mathrm{~V}]$ in 100 [s], using one produced generator. From the experimental result, it was confirmed that the produced linear generator was useful as an auxiliary power supply for the automobile. 


\section{永久磁石型リニアジェネレータの特性解析と試作}

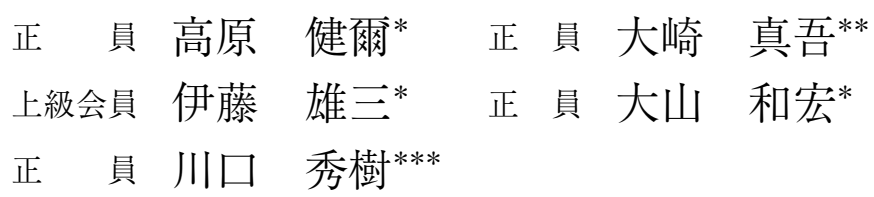

\section{Characteristic Analysis and Trial Manufacture of Permanent-Magnetic Type Linear Generator}

Kenji Takahara*, Member, Shingo Ohsaki**, Member, Yuzo Itoh*, Senior Member, Kazuhiro Ohyama*, Member, Hideki Kawaguchi***, Member

This paper describes design and trial manufacture of the linear generator, which can convert any mechanical vibration of an automobile to electric energy. A mover, which includes permanent magnets, is linearly driven through a stator, by vibrations. $\mathrm{Nd} \mathrm{Fe}-\mathrm{B}$ magnets in the mover are placed as same magnetic poles face mutually, in order to make the change of magnetic flux in the coils of the stator. The coils are placed in the stator with same intervals of magnets. The coils are wound for the reverse to the next coil and they are connected series all. A magnetic material case covers the stator makes the magnetic flax is extended through the case and decrease canceling the flux in the coils of the stator. Numerical simulations calculated distribution of the magnetic field, electromotive force and driven power of the mover in order to determine the size of the linear generator. The linear generator and an experimental apparatus were produced on the basis of the simulation, and its performance was tested by experiments. The produced linear generator was confirmed to be useful as an onboard auxiliary power supply.

キーワード :リニアジェネレータ, 振動, 磁場解析, 有限要素法, ディテントカ

Keywords: linear generator, vibration, magnetic field analysis, finite element method, detent force

\section{1. はじめに}

近年, 地球環境の悪化から, 環境にやさしい太陽光や風 力などに代表される様々なクリーンエネルギーの有効利用 に大きな関心が寄せられている。特に, 自動車では, 二酸 化炭素, 窒素酸化物など環境に悪影響を及ぼす有害ガスを 減らすために，電気自動車の実用化技術の開発が意欲的に 進められている(1)。一方で，これまで油圧で動作していた パワーステアリングやサスペンションなどの電気駆動シス テムへの変更や車内電装品の多様化により, 自動車での電

\footnotetext{
$*$ 福岡工業大学工学部電気工学科

干 811-0295 福岡市東区和白東 3-30-1

Dept. of Electrical Eng., Fukuoka Institute of Technology

3-30-1, Wajirohigashi, higashi-ku, Fukuoka 811-0295

** 新電元工業 (株)

干 100-0004 東京都千代田区大手町 2-2-1 新大手町ビル

Shindengen Co., Ltd.

New-Ohtemachi Bldg., 2-2-1, Ohtemachi, Chiyoda-ku,

Tokyo 100-0004

*** 室蘭工業大学工学部電気電子工学科

干 050-0071 室蘭市水元町 27-1

Dept. of Electrical and Electric Eng., Muroran Institute of Technology

27-1, Mizumoto-cho, Muroran 050-0071
}

力需要が増加している(2)(3)。これに対して, 車載電源の高電 圧化 ${ }^{(4)}$ や燃料電池の導入 ${ }^{(5)}$ が進められている。

自動車が走行するとき，必ず振動が発生する。これらの 振動は, 本来移動のために消費されるべきエネルギーが, 移 動体の動特性や移動時の環境によって, 無効エネルギーと して発生してきているものである。自動車などでは, 乗り 心地を良くしたり積載物を保護したりするために，バネや ショックアブソーバなどを用いて振動を吸収し, 熱に換え て廃棄している。この振動を電気エネルギーとして再利用 することができれば，より効率の良いエネルギー利用が実 現できると考えられる。

これまでに，直線運動を電気エネルギーに変換するリニ ア方式の発電機として提案されている基本的な構造は, 磁 石が直線運動するものとプランジャが直線動作するものに 大別される ${ }^{(6)}$ 。Wang らは, 移動体の振動を利用して発電す るために設計した特殊なバネを用いる方法を提案し, 小型 の発電機を試作している(7)。また, 永久磁石を用いて, エン ジンにより駆動されるもの ${ }^{(8)}$ も提案されている。あるいは, IC 駆動などを目的として, 数十 $[\mathrm{mW}]$ の低出力タイプ(9)(10) のものも提案されているが, 駆動源となる振動は周波数が 比較的高い。直線運動を電気エネルギーに变化する構造は 
単純であるが，回転機に比べて大きな磁束変化を得ること が容易ではない。大きな磁束変化を得るためには，駆動周 波数を大きく数十 $[\mathrm{Hz}]$ 以上とすればよいが, 自動車の摇動 などを利用するには大きな周波数となってしまう。

本研究者らは，これまで振動を駆動源とするリニアジェ ネレータの開発を移動子の永久磁石構造と固定子のコイル 配置を中心に行ってきた(11) (13)。それは，エネルギーを有 効利用するために，リニアジェネレータを自動車用サスペ ンションへ組み込み, 自動車で発生する振動を電気エネル ギーとして回収し, 電気二重層コンデンサなどへ充電して, 必要に応じて補助電源として利用することを想定している。

本論文では，まずリニアジェネレータの基本構造に基づ いて, 起電力ゃ, 発電電力, ディテント力などの基本特性 をシミュレーションする。そして, シミュレーション結果 に基づいて実機を試作し，発電実験を行ってその特性につ いて検討する。

\section{2. 設計と試作}

〈2・1〉 基本構造ここで対象とするリニアジェネレー 夕の基本構造を図 1 に示す。ジェネレータは円筒構造をし ており，ボタン型永久磁石と継鉄によって構成される移動 子が固定されたコイル内を移動する事により固定子に誘導 起電力を得るような構造となっている。

移動子には残留磁束の大きいネオジウム磁石を用い, 空 隙磁束密度を強め，それらの同極同士が向かい合うように 配置することで磁束が増大するような構造となっている。 固定子コイルをこれら磁石同士の間隔と等しく配置し, 隣 同士のコイルを逆方向に巻くことにより，コイルそれぞれ に発生する誘導起電力は, その位相が同期して強め合う構 造となっている。また外側を磁性体で覆い固定子継鉄を形 成し，これを通るような磁路を作ることで，移動子と固定子 間の鎖交磁束を強める構造をしている。以上のように，図 に示した基本構造にすることにより，磁束の変化量を大き くできると考えられる。

〈2·2〉 基本特性のシミュレーション 図 1 に示した基 本構造を軸対称場として, 有限要素法ソフトウエア ANSYS を用いて基本特性の動的シミュレーションを行った。まず,

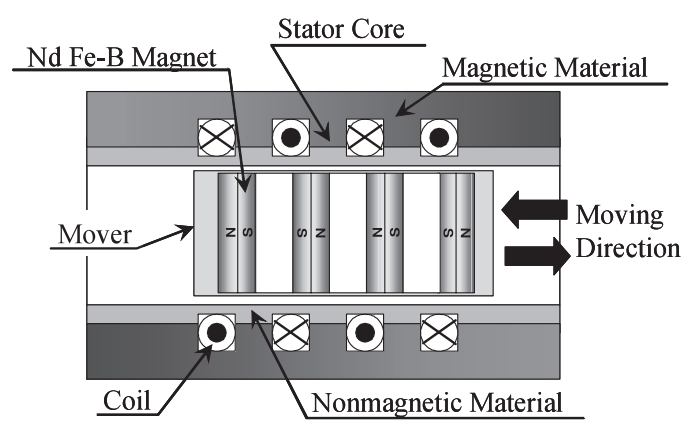

図 1 リニアジェネレータの基本構造

Fig. 1. Fundamental structure of the linear generator.
移動子が形成する磁場の様子を求めた。図 2 には, シミュ レーションに用いたモデルの構造と磁場分布の様子を示す。 なお，ここでは移動子として市販されているスーパーマグ ネットバー（マグネットジャパン製）を用いるものとして いる。これは, 直径 $25[\mathrm{~mm}]$ 長さ $200[\mathrm{~mm}]$ で, $2[\mathrm{~mm}]$ 間 隔で 7 個のネオジウム磁石の同極同士が向かい合うように 配置されたものである。その表面磁束密度は 1 [T] であり, 磁石 1 個あたりの保磁力を $923[\mathrm{kA} / \mathrm{m}]$ とした。コイルは 内径 $27.5[\mathrm{~mm}]$ から外径 $43.5[\mathrm{~mm}]$ まで巻かれており，そ の 1 つあたりの巻数を 1350 回とし，4 個を直列接続した。 コイルは，固定子継鉄で挟まれるようにスロットに納めら れるようになっている。固定子継鉄には，市販の鉄材を用 いるものとして, その比透磁率をあらかじめ測定した。具 体的には, 環状鉄材に巻線を施して B-H 曲線を求め, 使用 する範囲では非飽和であることを確認し，比透磁率を 800

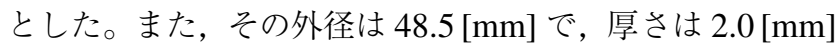
とした。

図 2 から，固定子継鉄を通るように磁路が形成されてい ることが確認できる。

自動車が走行する際に発生する振動は, 座席側で周波数

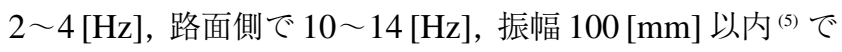
あるので, 移動子を $2.8[\mathrm{~Hz}]$, 振幅 $42[\mathrm{~mm}]$ で振動させた ときの出力電圧波形のシミュレーション結果を図 3 に示す。

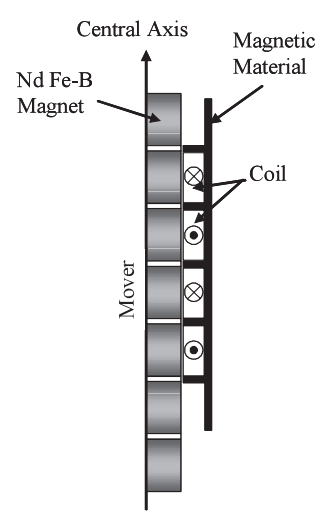

(a) Analytical Model

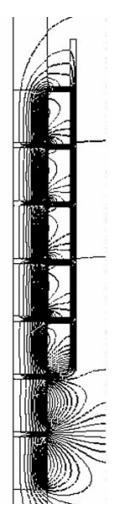

(b) Magnetic Field Distribution
図 2 解析モデルと磁場分布

Fig. 2. Analytical model and magnetic field distribution.

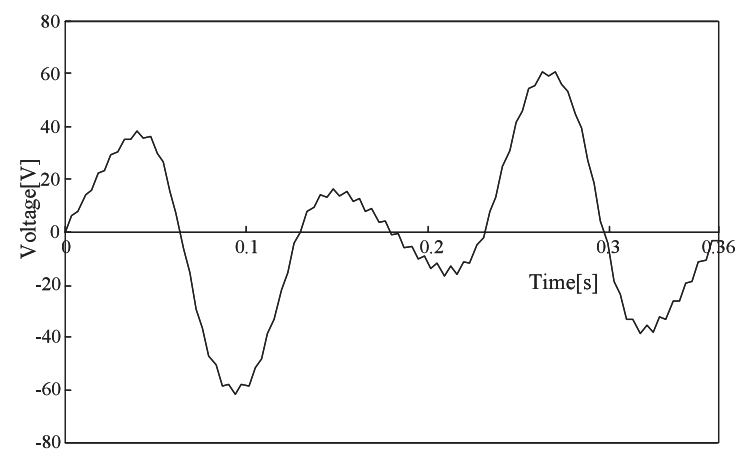

図 3 出力電圧波形のシミュレーション

Fig. 3. Simulation of the output voltage. 


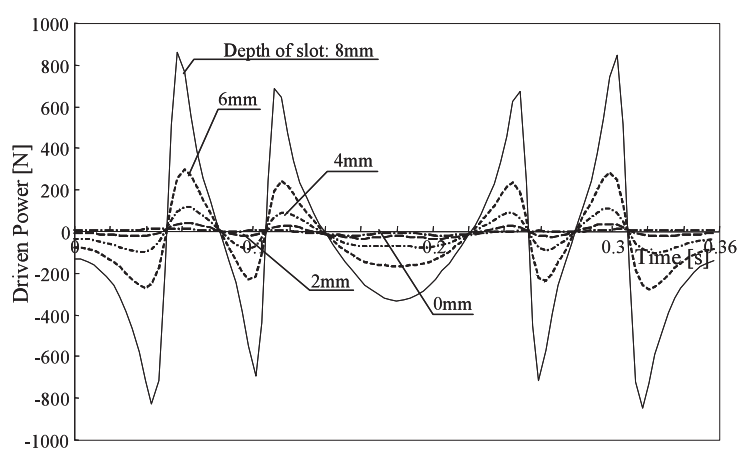

(a) Driven force changes in the stator coils opening

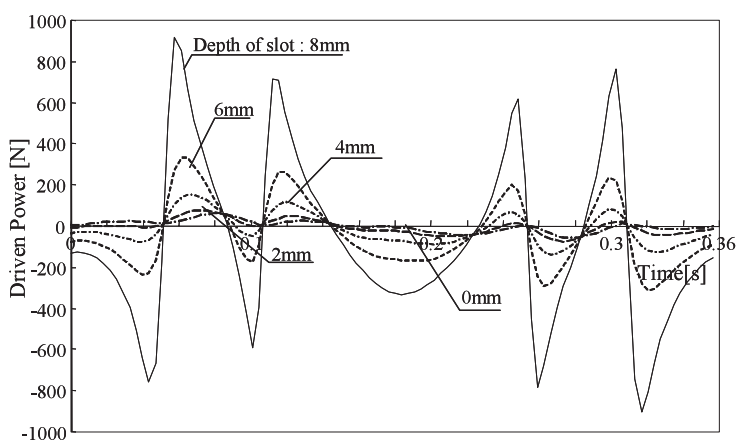

(b) Driven force changes in the stator coils short circuit

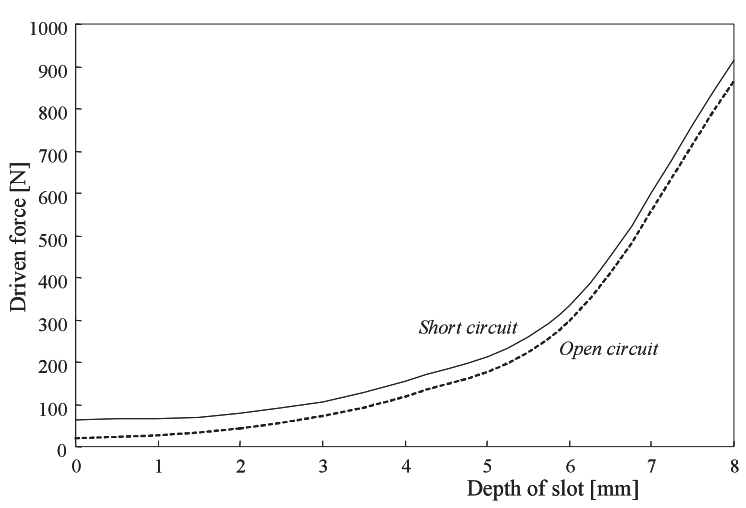

(c) Maximum value of driven force for the depth of the slot

図４スロットの深さに対する駆動力の比較

Fig. 4. Comparison of the driven force for the depth of the slot.

固定子長が有限なので，起電力はきれいな正弦波とはなっ てはいないが, 最大振幅 $62[\mathrm{~V}]$, 実効值 $31[\mathrm{~V}]$ が得られた。

強力な永久磁石を用いることは, 大きな起電力の発生に つながるが, ディテントカの増大を引き起こす。リニアジェ ネレータを自動車のサスペンション部分に組み込む場合に は，そのディテントカの脈動が本来のサスペンション機能 の特性に大きな影響を与えることにつながる。そこで，固 定子継鉄の最外側の外径と厚みは変更せずに，スロットの 深さを変えたときの移動子に対する駆動力の変化の様子を 図 4 に示す。ここで, 駆動力とは, 移動子を駆動するため の力を示している。なお，移動子は先のシミュレーション と同様の条件で動作させている。

図 4(a) および (b) は，それぞれ出力端を開放していると きと短絡しているときの移動子に対する駆動力の変化であ

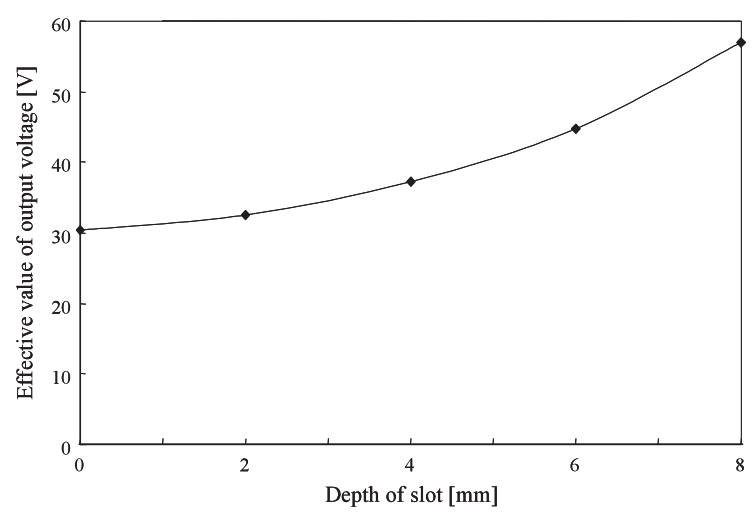

図 5 スロットの深さに対する出力電圧の実効值

Fig. 5. Effective value of output voltage for the depth of the slot.

り, (a) と (b) の差はコイルに流れる誘導電流が及ぼす影響を 示している。開放時，スロットの深さが最も大きい $8[\mathrm{~mm}]$ （移動子と固定子継鉄の空隙：0.5 [mm]）のときは駆動力の 最大值は 680 [N] となった。スロットをもたない円筒を用 いた場合には $62[\mathrm{~N}]$ となった。スロットが無い場合, ディ テントカは $0[\mathrm{~N}]$ となるはずであるが，コイルを納めるス ロットが有限長なので, 移動子が外に出た際に発生する吸 着力と, 固定子継鉄に発生するうず電流の影響により，駆 動力が発生していると考えられる。また, 同図 (b)では, コ イルに電流が流れることにより電機子反作用が起こるので, その值がディテントカに重㸚わされ, 移動子の駆動力の 変化は対称とはならない。計算の結果, スロットの深さが $8[\mathrm{~mm}]$ のとき, 駆動力の最大值は $743[\mathrm{~N}]$ となり, 円筒で は $82[\mathrm{~N}]$ であった。同図 (c) には, 開放時と短絡時におけ るスロットの深さと駆動力の最大值との関係を示している。 これにより，電機子電流による抗力はわずかであることが わかる。

図 5 には，移動子を先のシミュレーションと同様に動作 させ，スロットの深さに対する開放電圧の実効值の変化の 様子を示す。これよりスロットが深く, 移動子と固定子継 鉄の空隙が小さくなれば誘起電圧が大きくなることが示さ れている。シミュレーションによれば，継鉄がない場合で も $31[\mathrm{~V}]$ の開放電圧が得られた。一方で固定子の円筒直径 が一定ならば磁路断面積が減少するために磁気飽和の影響 を受けることが予想できる。

〈2·3〉 リニアジェネレータの試作シミュレーショ ンによれば，固定子側の継鉄のスロットの深さが大きいほ ど得られる電圧が大きいが，駆動力も大きくなることがわ かったので，固定子継鉄の形状をスロットがない円筒とし ても実効值で，一般的な車載バッテリの電圧 $12[\mathrm{~V}]$ 以上が 得られていることより, サスペンション性能に大きな影響 を与えないように円筒として試作した。試作機を図 6 に示 す。移動子には, ネオジウム磁石が 7 個, 同極同士が向かい 合わせに配置されている前述のスーパーマグネットバーを 用いた。固定子コイルは, 線径 $0.3[\mathrm{~mm}]$ の銅線を用いて, 


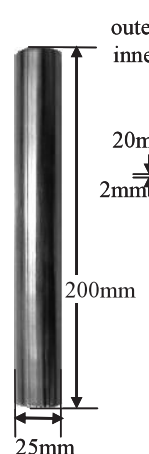

(a) Mover

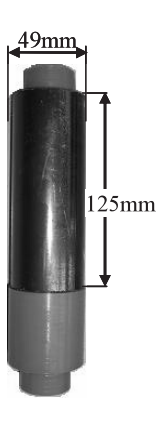

(b) Stator
困 6 試作機

Fig. 6. Experimental model.

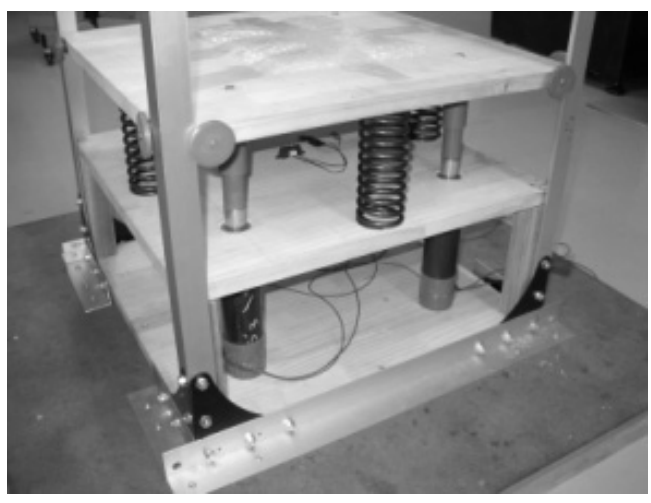

図 7 実験装置

Fig. 7. Experimental apparatus.

一つあたり 1350 回巻いた。固定子継鉄には厚さ $2[\mathrm{~mm}]$ の 鉄パイプ（比透磁率 800）を用いた。

〈2·4〉 実験装置の構成＼cjkstart試作機を駆動するために図 7 に示すようなサスペンション機能を模した実験装置を作製 した。この装置には試作機を 4 個配置した。この上面の可 動板に荷重を加えることで, 可動板とともに移動子に振動が 加わるような構造となっている。一般に，自動車のサスペ ンションに用いられるコイルスプリングのバネ定数は 20〜 $70[\mathrm{~N} / \mathrm{mm}]$ なので，ここでは，ばね定数を $23.6[\mathrm{~N} / \mathrm{mm}]$ に 設定した。

\section{3. 実験}

$\langle\mathbf{3} \cdot 1\rangle$ 出力特性実験装置に振幅 $48[\mathrm{~mm}]$, 周波数 $2.8[\mathrm{~Hz}]$ の振動を与えたときの固定子無負荷電圧波形を 図 8(a) に示す。同図 (b) には，可動板の平衡位置を 0 [mm] とした振動の様子を示した。比較のため，実測と同じ振動 を加えたときの開放電圧のシミュレーション結果を破線で 示した。電圧の時間変化の様子や振幅の大きさを比較すれ ば，ほぼ同じ傾向の波形が得られている。波形のずれにつ いては，本実験装置製作精度の関係から振動板と移動子の 動作を高精度に一致させることができず，その影響を受けた 結果となっている。実験の結果，固定子無負荷電圧の最大 振幅 $80[\mathrm{~V}]$, 実効值 33 [V] が得られた。なお, シミュレー

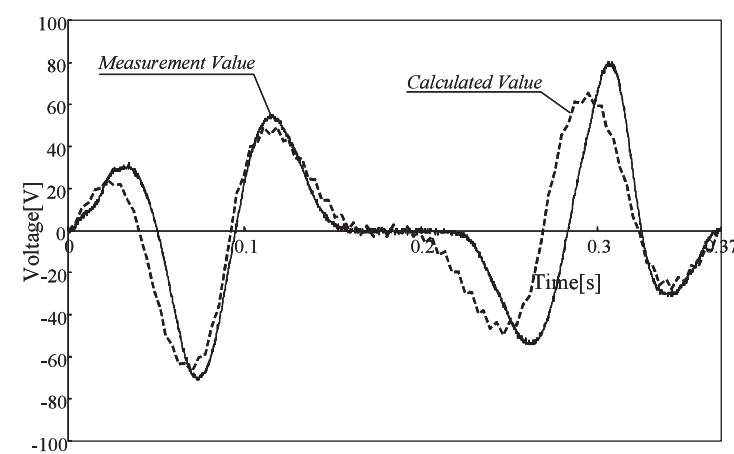

(a) Open voltage

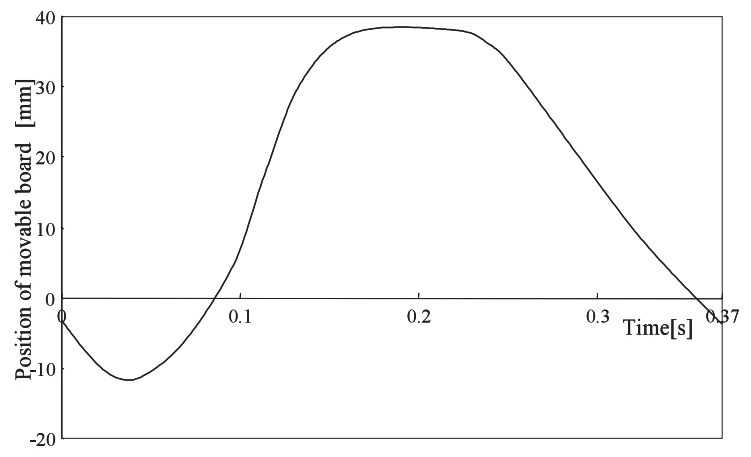

(b) Position of movable board

図 8 開放電圧

Fig. 8. Open voltage.

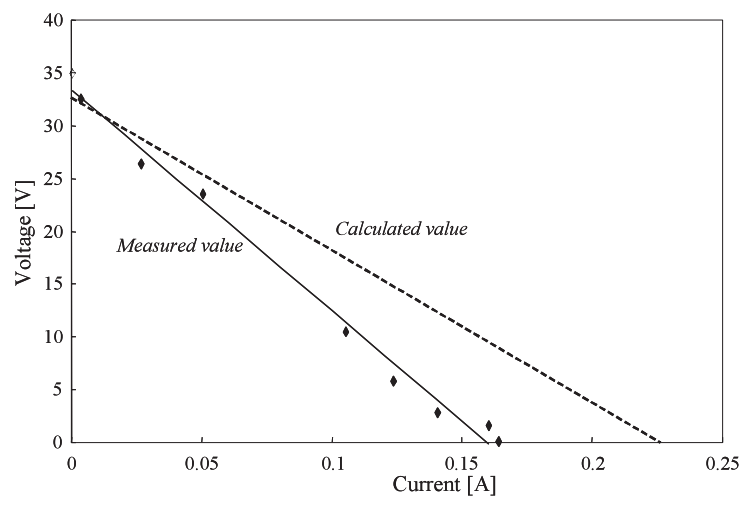

図 9 電流電圧特性

Fig. 9. Current-voltage characteristics.

ションでは, 最大振幅 $67[\mathrm{~V}]$, 実効值 32 [V] であった。

次に，同様の振動で移動子を駆動し，接続する負荷を変 化させて, 電流電圧特性を測定した。測定した電流電圧特 性を図 9 に示す。比較のために，シミュレーション結果を 同図中に破線で示す。開放電圧はほぼ一致しているが，短 絡電流がシミュレーションでは大きくなっている。これは, 実機では，シミュレーションに比べて交流実効抵抗成分が大 きくなっていることが原因であると考えられるが，十分に定 量化できていない。試作機の最大電力点を得る最適負荷は, 電圧電流特性に対して負荷抵抗を変化させた場合に，両者 の積が最大となる点を見出し，その值は抵抗 $200[\Omega]$ であっ た。ちなみに電圧 $16[\mathrm{~V}]$, 電流 0.08 [A] で, 電力 1.28 [W] 


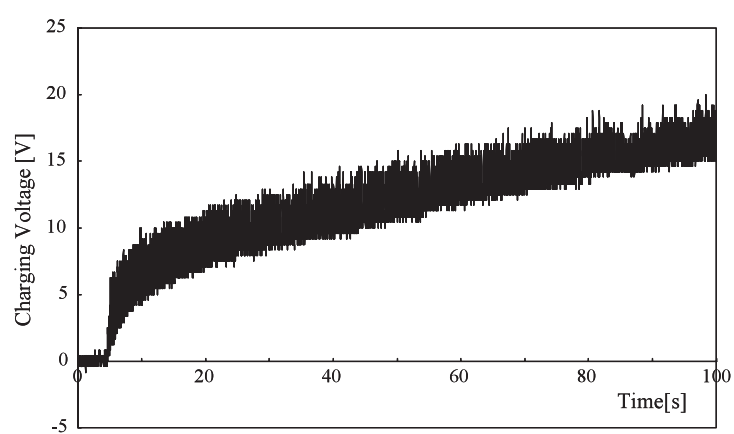

図 10 コンデンサへの充電電圧の変化

Fig. 10. Charging voltage to condenser.

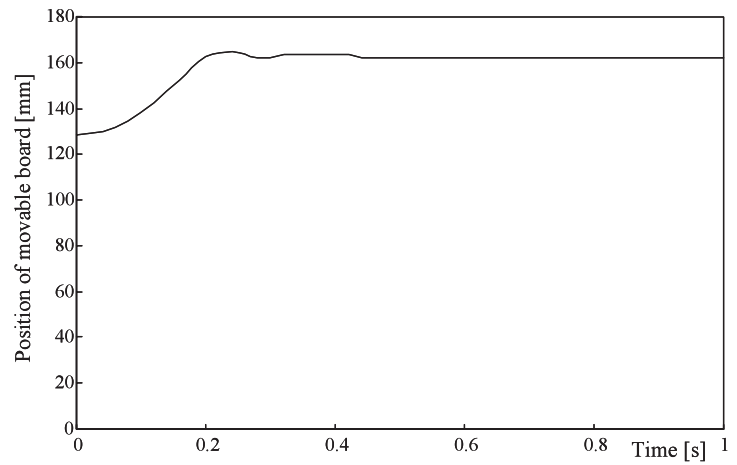

(a) Free vibration of the movable board in opening output termina

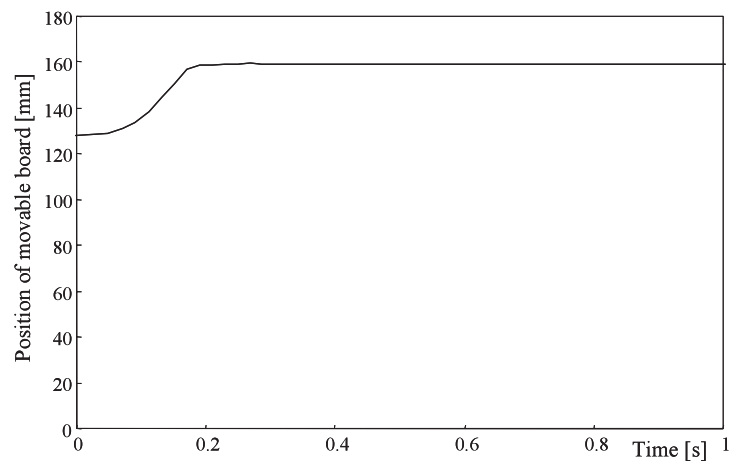

(b) Free vibration of the movable board in connecting the optimum load $200[\Omega]$ in output terminal

図 11 誘導電流による制動効果

Fig. 11. Damping effect by induced current.

が得られた。

提案するリニアジェネレータは，自動車が走行する際に 発生する振動により駆動され，得られた電力を直流化し補 助電源としてコンデンサへ充電することを想定している。 そこで，出力側をダイオードブリッジで全波整流し，0.5 [F] の電気二重層コンデンサへ充電実験を行った。先の実験と 同様の条件で移動子を駆動し，試作機 1 個を用いてコンデ ンサへ充電したときの電圧の変化を図 10 に示す。 1 個で は, 約 60 [秒] で 12 [V] まで, 100 [秒] では 16 [V] まで充電 することできた。実験結果から試作したリニアジェネレー 夕は, 既存の自動車用 12 [V] 電装品に供給可能な電圧が得 られることが確認できた。また，直列接続することにより，
36 [V] など高電圧化へのシフトにも対応することができる。

〈3・2〉 誘導電流によるダンピング＼cjkstart本研究では, でき るだけ自動車のサスペンション機能に影響を与えないよう にディテントカなどを低減するために，固定子側の継鉄部 分を円筒で製作した。しかしながら，発電時には誘導電流 によりダンピング作用が働く。その值は, シミュレーショ ンによれば, $20[\mathrm{~N}]$ 程度であった。ここでは, 実際に誘導 電流による減衰の効果について確認した。

可動板の上に, あらかじめ $70[\mathrm{Kg}]$ の重りを載せ，それを 取り外したときの板の振動を測定した。4 個のジェネレー 夕の出力端をすべて開放したときと, 各々すべてに最適負 荷である $200[\Omega]$ の抵抗を接続したときの実験結果をそれ ぞれ図 11 の (a) および (b) に示す。

実験装置本体のダンピング効果を定量化できていないの で，その効果を数值化できてはいないが，(a) と (b) を比較 すると, 固定子電流を流している場合の方がダンパー効果 がやや強く，振動が速く収束することが分かるが，それほ ど大きな効果ではないと考えられる。これは, 本試作機の 出力が 1.28 [W] と小さいことによるものである。試作機の 出力増大を図ることにより, 補助電源としての装着ととも に自動車のサスペンション機能としても期待できると思わ れる。

\section{4. おわりに}

本論文では自動車で発生する振動エネルギーを回生し, 有効利用することを目的として, 永久磁石型リニアジェネ レータを設計し, その諸特性を有限要素法により動的シミュ レーションを行った。シミュレーションに基づいて実機を 試作し, 振動を加えた発電実験を行いその特性を測定した。 その結果をまとめると下記の通りとなる。

（1）試作機を用いて電気二重層コンデンサに充電し, 車 載電装品へ供給可能な電圧を実現できることを確認した。

（2）ディテント力を含めた駆動力と発電電力は, スロッ 卜深さの増加に対して大きくなるが，例えば発電容量を低 下させずにディテントカのみを低減するために，スロット 形状を検討する必要がある。

（3）自動車への実装のためには振動に対する減衰力等 の定量的な評価を行い, 既存のサスペンション機能との差 異を検討する必要がある。

今後，インバー夕を用いて電力制御を行う場合の特性に 関する検討を行う予定である。また，提案したジェネレー 夕の振動に対する制動効果を大きくして, セミアクティブ サスペンションを構成するための, 最適インピーダンスの 選定方法およびリニアジェネレータに相応しい制御方式に 関する検討を行う必要がある。

\section{謝 辞}

本研究の一部は, 福岡工業大学総合研究機構エレクトロ ニクス研究所の平成 17 年度特別研究助成費により遂行さ れました。ここに感謝の意を表します。

(平成 18 年 9 月 28 日受付, 平成 19 年 2 月 6 日再受付) 


\section{文献}

(1) Inst. of Electrical Engineers of Japan and electric vehicle propulsion system enquiry expert committee: "The newest technology of electric automobile", Ohm-sha, Tokyo (1999) (in Japanese)

電気学会・電気自動車駆動システム調査専門委員会 :「電気自動車 の最新技術」, オーム社, 東京 (1999)

(2) J. Ishii and M. Amano: "Present condition and prospect of the power electronics for an automobile", J. IEE. Jap, Vol.122, No.6, pp.371-373 (2002)

(3) T. Teratani: "Present condition and prospect of the automobile power supply", J. IEE. Jap, Vol.122, No.6, pp.356-359 (2002)

(4) T. Honma: "Illustrated all of the fuel cells", Kogyo Gijutsu Chosa-kai, Tokyo (2003) (in Japanese)

本間环也：「図解燃料電池のすべて」, 工業技術調査会, 東京 (2003)

( 5 ) KYB Co., Ltd.: “Automotive Suspension 2nd Ed.", Sankai-do, Tokyo (2005) (in Japanese)

カヤバ工業株式会社 : 「自動車のサスペンション第 2 版」, 山海堂, 東 京 (2005)

(6) I. Boldea and S.A. Nasar: "Linear electric actuators and generators", IEEE Trans. Energy Conversion, Vol.14, No.3, pp.712-717 (1999)

( 7 ) J. Wang, W. Wang, G.W. Jewell, and D. Howe: "Design and experimental characterization of a linear reciprocating", IEE Proc-Electr. Power Appl., Vol.145, No.6, pp.509-518 (1998)

(8) W.R. Cawthorne, P. Famouri, J. Chen, N.N. Clark, T.I. McDaniel, R.J. Atkinson, S. Nandkumar, C.M. Atkinson, and S. Petreanu: "Development of a linear alternator-engine for hybrid electric vehicle applications", IEEE Trans. Vehicular Thecnology, Vol.48, No.6, pp.1797-1802 (1999)

(9) J. Okazaki, K. Shikama, H. Yamakawa, H. Hosaka, and K. Itao: "Design of automatic power generator using mechanical vibration", MIcromechatronics, Vol.46, No.1, pp.29-37 (2001) (in Japanese)

岡崎 潤・鹿間宏一・山川 博・保坂 寛・板生 清:「機械振動を 用いた自動発電システムの研究」, マイクロメカトロニクス, Vol.46, No.1, pp.29-37 (2001)

(10) J. Wang: "A Low-Power, Linear, Permanent-Magnet Generator/Energy Storage System", IEEE transactions on industrial electronics, Vol.49, No.3, pp.640-648 (2002)

(11) K. Takahara, H. Nozaki, K. Kawaguchi, and Y. Itoh: "Prototype of a Linear Power Generator", Proc. 34th. Hokkaido Chap. SICE., pp.101-102 (2004) (in Japanese)

高原健爾・野崎久司・川口秀樹・伊藤雄三 :「リニアパワージェネ レータの試作」, 第 36 回計測自動制御学会北海道支部学術講演会論 文集, pp.101-102 (2004)

(12) K. Takahara, S. Ohsaki, H. Kawaguchi, and Y. Itoh: "Development of linear power generator: Conversion of vibration energy of a vehicle to electric power", Journal of Asian Electric Vehicles, Vol.2, No.2, pp.639-643 (2004)

(13) K. Takahara, S. Ohsaki, K. Ohyama, H. Kawaguchi, and Y. Itoh: "Electric power acquisition from the vibration of an electric vehicle using a permanent magnetic linear power generator", Journal of Asian Electric Vehicles, Vol.3, No.2, pp.829-835 (2005)

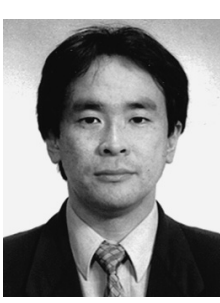

（正員） 1966 年 1 月 11 日生。 1997 年 3 月東京 医科歯科大学大学院医学系研究科博士課程単位取 得退学。同年 4 月室蘭工業大学工学部電気電子工 学科助手。2005 年 4 月福岡工業大学工学部電気 工学科助教授。現在に至る。博士 (工学)。

（正員） 1981 年 7 月 20 日生。 2006 年 3 月室蘭 工業大学工学研究科電気電子工学専攻修士課程修

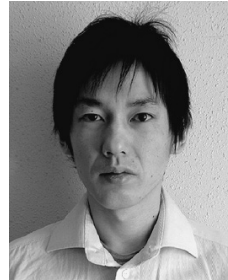
了。現在, 新電元工業（株）にて, 二輪用電装品 の回路設計に従事。

伊 藤 雄 三

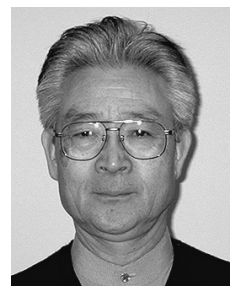

大山和宏

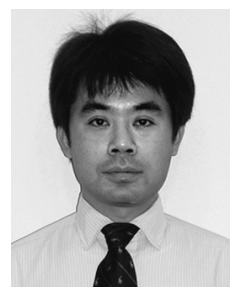

（正員） 1970 年 9 月 23 日生。1998 年 3 月鹿児 島大学大学院システム情報工学専攻博士後期過程 修了。同年 4 月より 1 年間ノッティンガム大学 客員研究員。1 1999 年 4 月福岡工業大学工学部講 師， 2002 年 4 月同助教授となり現在に至る。主 として，交流機のセンサレス制御に関する研究に 従事。博士 (工学)。

川口 秀 樹 (正員) 1962 年 12 月 3 日生。1988 年 3 月北海

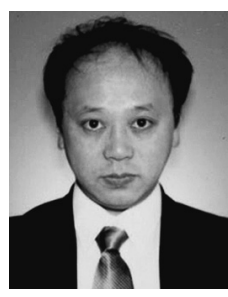
道大学大学院工学研究科修士課程電気工学専攻修 了。同年，日本電信電話（株）NTT 情報通信処理 研究所入社。1 1991 年 4 月北海道大学工学部電気 工学科助手。1999 年 4 月室蘭工業大学電気電子 工学科助教授。この間，1995 年 12 月 1996 年 9 月文部省在外研究員 (ダルムシュタット工科大 学, ドイッ)。主に, 電磁界解析, ビーム物理工 学, ハイパフォーマンスコンピューティングに関する研究に従事。博 士 (工学)。 